\title{
Kontaminace př́břežních sedimentárních těles řeky Odry u Bohumína organickými polutanty
}

\section{Contamination of channel side bars of the Odra River near Bohumín by organic pollutants}

\author{
Jan Sedláček ${ }^{1} \rightrightarrows$, Jitka Tolaszová², Martin Žídek ${ }^{1}$ \\ ${ }^{1}$ Katedra geologie PřF UP, 17. listopadu 1192/12, 77146 Olomouc, ČR \\ ${ }^{2}$ Fakulta životního prostředí, Univerzita J. E. Purkyně v Ústí nad Labem, Pasteurova 3544/1, 40096 Ústínad Labem-město, ČR
}

Key words:

Channel side bars, Grain size, Total organic carbon, Persistent organic pollutants, Emission sources, Specific biomarkers

$凸$ jan.sedlacek@upol.cz

Editor:

Pavla Tomanová Petrová

\begin{abstract}
The aim of this study is to investigate present-day contamination levels of selected organic pollutants (POPs) in channel side bars and identify their sources. The studied area is located on the Odra River in the north-eastern part of the Czech Republic (at the border between the Czech Republic and Poland), between the city Bohumin and Odra's confluence with Olše River. Sediment samples were taken directly from the channel side bars and subsequently measured for grain size analysis, concentrations of total organic carbon (TOC), polycyclic aromatic hydrocarbons (PAHs), polychlorinated biphenyls (PCBs), organochlorine pesticides (OCPs) and specific biomarkers (terpenoids). Three main facies were recognized in channel side bars. Grain-size analysis showed the predominance of silt fraction, followed by variable sand contents, whereas the contents of clay fraction were almost stable. No statistically significant correlation was found between grain size and the concentrations of POPs except a weak correlation between PAHs, PCBs and sand fraction. POPs including $P A H s, P C B$ s and OCPs showed high variability. In all samples, the sum of PAHs (maximum value of $78.1 \mathrm{mg} \mathrm{kg}^{-1}$ ) greatly exceeded the Czech preventive limit for dry soil. The sources of $P A H s$ were analysed by employing diagnostic ratios and plots of specific PAH compounds. The results showed a high degree of correspondence suggesting a petrogenic origin associated with direct input into the river system. Relatively high concentrations of PAHs are a consequence of the vicinity of the pollution source and location in natural river reach enabling sedimentation of polluted sediments. Concentrations of $P C B$, hexachlorobenzene and DDT metabolites were almost insignificant in most of the samples, except for several samples having higher PCB values (maximum value of $47.6 \mu \mathrm{g} \mathrm{kg}^{-1}$ ). Specific biomarker compounds were used as an indicator of the presence of fossil matter, and $H 2917 \alpha(H), 21 \beta(H)$ hopane showed the highest concentrations. The homohopane index indicated petroleum and vehicle exhausts origin. TOC revealed a positive correlation with specific biomarkers (homo hopanes and $16 \alpha(H)$ - phyllocladane, hexachlorbenzene and PCB.
\end{abstract}

\section{Úvod}

V minulých dekádách bylo do životního prostředí uvolněno velké množství toxických organických látek, souborně označovaných jako perzistentní organické polutanty, mezi nimiž jsou nejtypičtější polycyklické aromatické uhlovodíky (PAU), polychlorované bifenyly (PCB) a organochlorované pesticidy (OCP). Odpadní vody a posléze fluviální systémy představují hlavní transportní prostředí pro sedimenty a také pro organické polutanty. Fluviální sedimenty byly rozpoznány jako významný př́ijemce znečištění. Organické polutanty jsou ve vodním prostředí vázány na pevné částice a poté se ukládají v sedimentech (PAU a PCB jsou hydrofobní povahy). Sorpce organických polutantů na sediment je ovlivněna 
zrnitostí a jeho složením, zejména množstvím a typem organické hmoty (Konat a Kowalewska 2001; Kleineidam et al. 2002; Hofmann et al. 2007). V oblastech ovlivněných těžbou uhlí byla prokázána sekundární sorpce PAU na uhelnou hmotu v sedimentech (Hofmann et al. 2007; Yang et al. 2008; Sedláček et al. 2020). Některé organické polutanty byly kvůli jejich vysoké biotoxicitě zakázány (Konat a Kowalewska 2001; Covaci et al. 2006), avšak vzhledem k jejich vysoké perzistenci jsou stále v životním prostředí př́tomny v nezanedbatelném množství. Neznámé množství těchto látek může být uloženo $\mathrm{v}$ industriálních oblastech, což může představovat podstatné riziko ekologické zátěže fluviálních systémů. Na území ČR je jednou z těchto oblastí ostravská aglomerace, v jejímž okolí byly sledovány zvýšené koncentrace organických polutantů v několika depozičních prostředích (Janáková et al. 2010; Geršlová a Schwazbauer 2014; Sedláček et al. 2020). Během povodňových událostí může dojít $\mathrm{k}$ remobilizaci těchto zátěží, což znamená riziko šíření kontaminace. Cílem této studie je zjistit míru současných koncentrací vybraných organických polutantů v příbřežních sedimentárních tělesech řeky Odry v úseku toku s. od Bohumína, jelikož toto území poskytuje excelentní příklad depozičního prostředí ovlivněného industriálním regionem ostravské aglomerace. Dalším cílem studie bude interpretace původu kontaminace organickými polutanty.

\section{Metodika}

Vzorky byly odebrány přímo z příbřežních těles řeky Odry v říjnu roku 2019 na pěti odběrových místech (celkem 14 vzorků, obr. 1) do alobalové fólie. Hmotnost každého vzorku byla cca 30-50 g. Cílem terénních prací bylo odebrat na každém sedimentárním tělese několik vzorků z různých facií. Vzorky sedimentu byly bezodkladně odeslány na analýzy organických polutantů, které proběhly na Fakultě životního prostředí UJEP v Ústí nad Labem. Vzorky byly nejprve lyofilizovány na prŕstroji Scanvac (Trigon plus, Česká republika). K extrakci (extrakční technika QuEChERS) v MiniG 1600 (SPEX ${ }^{\oplus}$ SamplePrep, USA) bylo do polypropylenových zkumavek (Fisher Scientific, ČR) naváženo 5 g vzorku. Sediment byl obohacen $0,1 \mathrm{ml}$ roztoku deuterovaných standardů o koncentraci $10 \mu \mathrm{g} /$ $\mathrm{ml} v$ acetonu pro PAU a dále extrahován směsí rozpouštědel - 20 ml etylacetátu a vody v poměru 1: 1 (obj./obj.). Byly přidány soli $\mathrm{MgSO}_{4}$ (4 g) a NaCl (1 g). Zkumavky byly umístěny do vertikální třepačky MiniG na 5 min při 1500 ot./min. Po ukončení třepání se zkumavky se vzorky odstředily (centrifuga Remi X5 R-10 M, Chromservis, ČR a Biosan Microspin 12, Merci, ČR) prri 4500 ot./min po dobu $5 \mathrm{~min}$. Poté se supernatant přefiltroval přes nylonový stříkačkový filtr o velikosti $0,22 \mu \mathrm{m}$ a filtrát byl odebrán do $2 \mathrm{ml}$ skleněné vialky. Výtěžnost PAU (extrakční technika QuEChERS) byla vždy vyšší než $80 \%$.

K separaci sloužila kolona Rxi PAH $40 \mathrm{~m} \times 0,18 \mathrm{~mm}$, 0,07 $\mu \mathrm{m}$ (Restek, USA) a kolona DB-EUPAH $20 \mathrm{~m} \times$ $0,18 \mathrm{~mm}, 0,14 \mu \mathrm{m}$ pro stanovení PAU a terpenů (Agilent Technologies, USA) a pro OCP a PCB kolona HP5-MS $30 \mathrm{~m} \times 0,25 \mathrm{~mm}, 0,25 \mu \mathrm{m}$ (Agilent Technologies, USA). Extrakty sedimentu byly měřeny na plynovém chromatografu (7890B, Agilent Technologies, USA) s hmotnostním spektrometrem (7000D trojitý kvadrupól, Agilent Technologies, USA). Vyhodnocení dat proběhlo v softwaru MassHunter verze B.09.00 od Agilent Technologies. Stanovení celkového organického uhlíku (TOC) bylo provedeno na analyzátoru Scalar analytical TOC analyzer (Breda, Nizozemí). Podíl TOC byl spočítán z rozdílu mezi celkovým (TC) a anorganickým uhlíkem (IC). Celkový uhlík byl stanoven po katalytické oxidaci vzorku (300 mg) při teplotě $1100^{\circ} \mathrm{C}$ a podíl anorganického uhlíku byl zjištěn okyselením vzorku $(100 \mathrm{mg}) 20 \% \mathrm{H}_{3} \mathrm{PO}_{4}$ (doporučeno výrobcem) při teplotě $150^{\circ} \mathrm{C}$. Pro kalibraci př́stroje byl použit $\mathrm{CaCO}_{3}$. Zrnitostní rozbor byl proveden za pomocí laserového granulometru Analysette 22 MicroTec plus (Fritsch, SRN) na katedře geologie Univerzity Palackého v Olomouci.

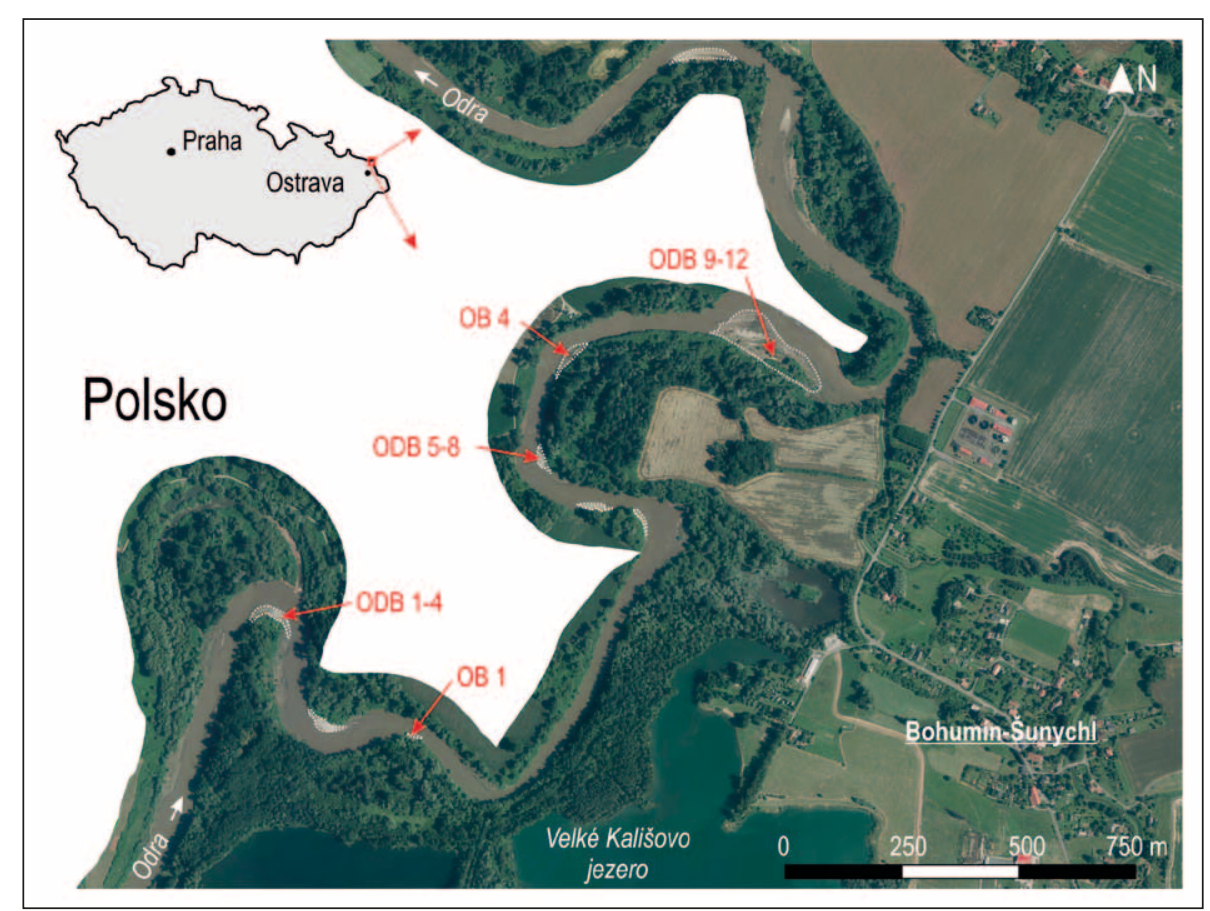

Obr. 1: Lokalizace studované oblasti s vyznačením př́ibrežních sedimentárních těles a míst odběru vzorků.

Fig. 1: Location of studied area and sampling sites, channel side bars marked. 


\section{Popis lokality a výsledky}

Zájmové území (obr. 1) se nachází na toku řeky Odry mezi Bohumínem a soutokem s řekou Olší. Jedná se o krátký úsek přirozeně meandrující řeky Odry s místy rozsáhlými říčními náplavy štěrkové a písčité povahy. Tento úsek se vyznačuje velkou dynamikou se dvěma mrtvými rameny. Území je součástí přírodní památky Hraniční meandry řeky Odry, což je 7,5km dlouhý úsek s několika zákruty, jehož středem probíhá státní hranice mezi Českou republikou a Polskem. Průměrný roční průtok (Q1) řeky Odry činí 48,1 m³/s (KS Bohumín, ČHMÚ), pro srovnání hodnota stoletého průtoku (Q100) je 1810 $\mathrm{m}^{3} / \mathrm{s}$. Historická maxima průtoku byla dosažena během povodní v letech $1985\left(732 \mathrm{~m}^{3} / \mathrm{s}\right), 1997\left(2160 \mathrm{~m}^{3} / \mathrm{s}\right)$ a 2010 $\left(1067 \mathrm{~m}^{3} / \mathrm{s}\right)$.

Velikost př́ibřežních těles byla variabilní, největší z nich dosahovalo rozměrů cca $270 \times 25 \mathrm{~m}$ a nejmenší cca $40 \times 15 \mathrm{~m}$. Všechna tato sedimentární tělesa leží za normálního průtoku nad hladinou řeky a byly $\mathrm{v}$ nich pozorovány tř̌i hlavní facie a to štěrkovitá, písčitá a jílovitá. Jemnozrnnější facie tvoří většinou pouze několik $\mathrm{cm}$ mocnou vrstvu, která byla uložena pravděpodobně $\mathrm{v}$ důsledku poklesu energie proudění po proběhlé povodňové události a jedná se o relativně čerstvě usazený materiál. Granulometrický rozbor, přepočítaný na procentuální zastoupení jednotlivých frakcí (tab. 1), poukázal na dominanci prachovité frakce s podíly od 59,9 do $78,3 \%$. Podíly písčitých frakcí vykazovaly variabilnější charakter a pohybovaly se od 5,8 do $29,8 \%$. Z toho většina připadala na velmi jemnozrnný a jemnozrnný písek, částice větší než $0,5 \mathrm{~mm}$ nebyly pozorovány. Podíl jílové frakce byl bez výraznějších výkyvů v rozmezí od 9 do 19,9\%. Celkově lze vzorky klasifikovat jako písčitý prach.

Koncentrace sedmnácti základních homologů PAU [naftalen, acenaftylen, acenaften, fluoren, fenantren, antracen, fluoranten, pyren, benzo(a)antracen, chrysen, benzo(b)fluoranten, benzo(k)fluoranten, benzo(j)fluoranten, benzo(a)pyren, dibenzo(a,h)antracen, benzo(ghi) perylen a indeno(1,2,3-cd)pyren] - (tab. 2), se pohybovala v rozmezí od 6,7 do $78,1 \mathrm{mg} / \mathrm{kg}$ s mediánem $19,6 \mathrm{mg} / \mathrm{kg}$. Nejvíce zastoupené homology jsou fluoranten, pyren a benzo(b)fluoranten (E-prríloha 1). Diagnostické poměry a diagramy PAU (obr. 2), přestože mají určitá omezení, mohou poskytnout informace o způsobu vzniku, původu nebo charakteru spalované biomasy, resp. fosilních paliv. Každý zdroj emisí PAU je charakteristický vznikem určitých typů sloučenin (Yunker et al. 2002; Tobiszewski a Namiesnik 2012). V této studii byly použity různé poměry a diagnostické diagramy pro přesnější interpretaci. Poměr LMW/HMW (nízkomolekulární/vysokomolekulární PAU) se u vzorků pohyboval v úzkém rozpětí od 1,22 do 1,78 . Hodnoty $>1$ poukazují na petrogenní původ, zatímco nižší značí pyrogenní původ. Ke stejnému účelu byl použit poměr Fla/Pyr s hodnotami od 1,25 do 1,43 a hodnoty vyšší než jedna opět indikují petrogenní po̊vod. Dále byly použity diagnostické dvouosé diagramy Fla/Fla + Pyr versus LMW/ HMW a LMW/HMW versus BaA/ $(\mathrm{BaA}+\mathrm{Chr})$.
Tab. 1: Výsledky zrnitostního rozboru znázorňující procentuální zastoupení jednotlivých frakcí. VF = velmi jemnozrnný písek, $\mathrm{F}=$ jemnozrnný písek, $\mathrm{M}=$ střednozrnný písek, $\mathrm{C}=$ hrubozrnný písek, $\mathrm{VC}=$ velmi hrubozrnný písek.

Tab. 1: Grain size data showing the percentage of individual fractions. $\mathrm{VF}=$ very fine sand, $\mathrm{F}=$ fine sand, $\mathrm{M}=$ medium sand, $\mathrm{C}=$ coarse sand, $\mathrm{VC}=$ very coarse sand.

\begin{tabular}{|l|c|c|c|c|c|c|c|}
\hline \multirow{2}{*}{ Vzorek } & \multicolumn{7}{|c|}{ Zrnitostní frakce } \\
\cline { 4 - 8 } & \multirow{2}{*}{ Jíl } & \multirow{2}{*}{ Prach } & \multicolumn{5}{|c|}{ Písek } \\
\cline { 4 - 8 } & & & VF & $\mathrm{F}$ & $\mathrm{M}$ & $\mathrm{C}$ & VC \\
\hline ODB 1 & 13,4 & 71,7 & 13,2 & 1,7 & 0 & 0 & 0 \\
\hline ODB 2 & 14,1 & 69,7 & 14,6 & 1,6 & 0 & 0 & 0 \\
\hline ODB 3 & 13,6 & 62,6 & 16,0 & 7,8 & 0 & 0 & 0 \\
\hline ODB 4 & 10,3 & 59,9 & 17,3 & 11,0 & 1,6 & 0 & 0 \\
\hline ODB 6 & 12,3 & 73,9 & 13 & 0,7 & 0 & 0 & 0 \\
\hline ODB 7 & 9,03 & 64,8 & 15,4 & 7,9 & 2,8 & 0 & 0 \\
\hline ODB 8 & 13,1 & 72,0 & 14,1 & 0,9 & 0 & 0 & 0 \\
\hline ODB 9 & 15,9 & 78,3 & 5,8 & 0 & 0 & 0 & 0 \\
\hline ODB 11 & 12,2 & 77,7 & 10,1 & 0,1 & 0 & 0 & 0 \\
\hline ODB 12 & 15,0 & 72,8 & 11,9 & 0,4 & 0 & 0 & 0 \\
\hline OB 4 & 10,5 & 74,4 & 14,1 & 1,1 & 0 & 0 & 0 \\
\hline
\end{tabular}

Tab. 2: Koncentrace PAU, PCB a HCB ve studovaných vzorcích. Tab. 2: Concentrations of PAHs, PCBs and HCB in the studied samples.

\begin{tabular}{|l|c|c|c|c|c|}
\hline \multirow{2}{*}{ Vzorek } & $\mathbf{m g} / \mathbf{k g}$ & \multicolumn{3}{|c|}{$\boldsymbol{\mu g} / \mathbf{k g}$; pod mezí stanovitelnosti } \\
\cline { 2 - 6 } & $\Sigma$ PAU & $\Sigma$ PCB & HCB & DDE-p,p & DDD-p,p \\
\hline ODB 1 & 29,8 & 9,9 & 2,6 & 6,6 & 4,3 \\
\hline ODB 2 & 19,7 & 13,1 & 2,5 & 5,2 & 5,0 \\
\hline ODB 3 & 72,7 & 24,0 & 2,9 & 6,0 & 5,6 \\
\hline ODB 4 & 34,8 & 35,3 & 2,3 & 6,3 & 5,4 \\
\hline ODB 5 & 61,2 & 1,0 & 1,8 & 3,1 & $<$ \\
\hline ODB 6 & 8,6 & 10,4 & 2,3 & 7,0 & 6,6 \\
\hline ODB 7 & 20,5 & 12,1 & 3,2 & 6,1 & 4,7 \\
\hline ODB 8 & 14,0 & 14,6 & 2,6 & 6,8 & 4,8 \\
\hline ODB 9 & 13,2 & 11,4 & 2,8 & 6,3 & 4,7 \\
\hline ODB 10 & 6,2 & 1,0 & 1,7 & $<$ & $<$ \\
\hline ODB 11 & 8,9 & 6,3 & 2,3 & 4,7 & $<$ \\
\hline ODB 12 & 18,0 & 9,2 & 2,6 & 6,8 & 5,0 \\
\hline OB 1 & 15,2 & 23,4 & 4,1 & 7,0 & 5,8 \\
\hline OB 4 & 18,1 & 47,6 & 4,3 & 7,2 & 5,2 \\
\hline
\end{tabular}

U perchlorovaných bifenylů bylo stanoveno šest kongenerů (PCB 28, PCB 52, PCB 101, PCB 153, PCB 138 a PCB 180) - (E-pŕíloha 2). Jejich celkové koncentrace (tab. 2) byly vesměs nízké a pohybovaly se od 1 do 47,6 $\mu \mathrm{g} / \mathrm{kg}$ s mediánem $11,7 \mu \mathrm{g} / \mathrm{kg}$. Ovšem některé kongenery (PCB 52, PCB 101 a PCB 153) byly téměř ve všech vzorcích pod mezí stanovitelnosti. DDT (dichlordifenyltrichlorethan) nebyl ve vzorcích zjištěn, pouze jeho metabolity DDD-p, $\mathrm{p}^{\prime}$ (dichlordifenyldichlorethan) a DDE-p,p'(dichlordifenyldichlorethylen), ovšem v nízkých koncentracích do $7 \mu \mathrm{g} / \mathrm{kg}$ a v některých vzorcích byly oba metabolity pod mezí stanovitelnosti. Na nízké úrovni jsou taktéž koncentrace hexachlorbenzenu (HCB), hodnoty u všech vzorkủ byly velmi podobné a pohybovaly se v rozmezí od 1,7 do $4,3 \mu \mathrm{g} / \mathrm{kg}$ s mediánem $2,6 \mu \mathrm{g} / \mathrm{kg}$ (tab. 2). Dále byly sledovány vybrané biomarkery, jakožto indikátor př́tomnosti fosilní organické hmoty. Hopany (pentacyklické triterpeny) slouží jako biomarkery pro 


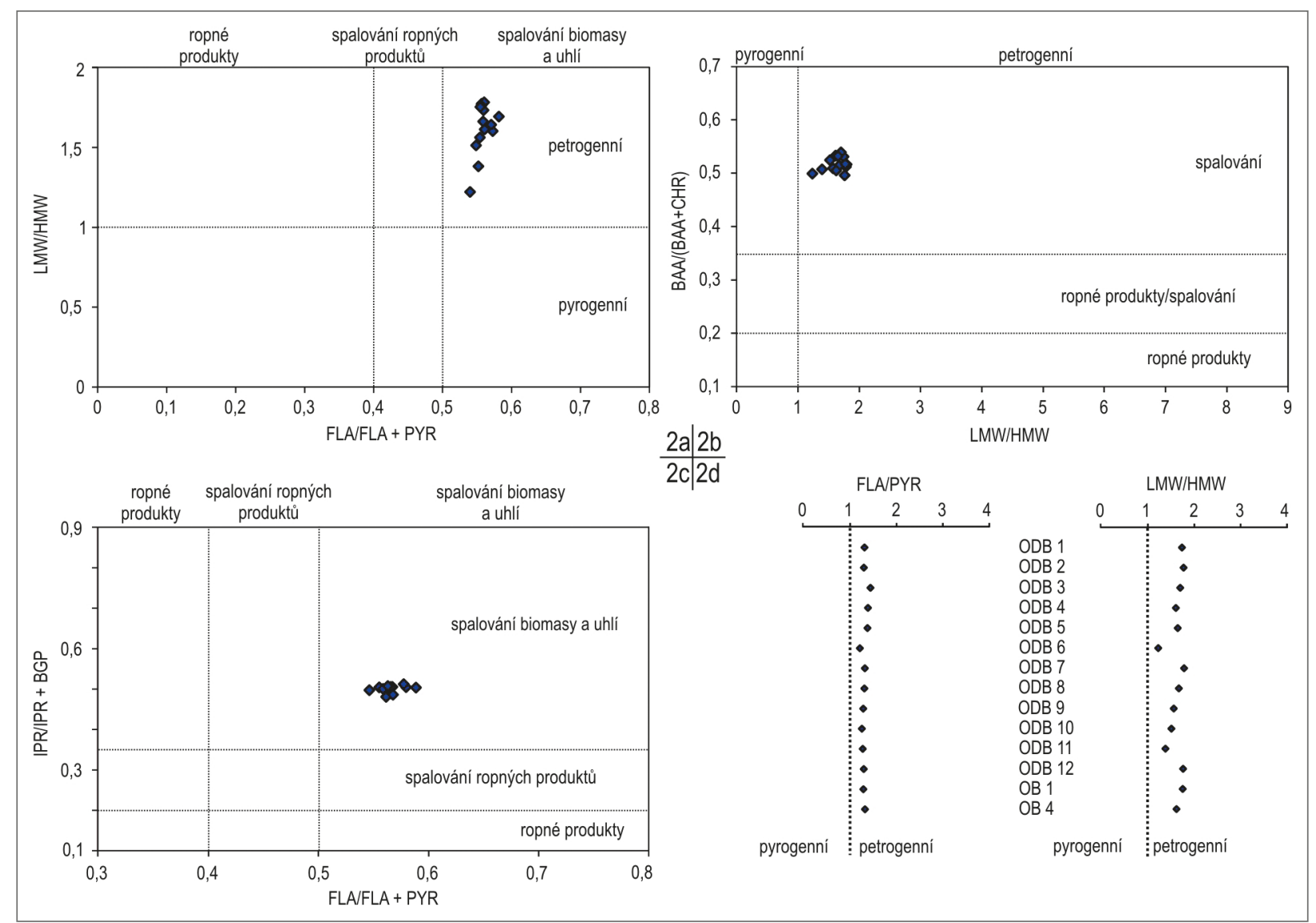

Obr. 2: Diagnostické dvouosé diagramy a poměry PAU. (a) FLA/FLA + PYR ku LMW/HMW, FLA = fluoranten, PYR = pyren; LMW/HMW = nízkomolekulární/vysokomolekulární PAU; (b) LMW/ HMW ku BAA/(BAA + CHR), BAA = benz[a]antracen, CHR = chrysen; (c) FLA/FLA + PYR ku IPR/IPR + BGP, IPR = indeno[1,2,3- cd]pyren, BGP = Benzo[g,h,i]perylen; (d) Diagnostické poměry FLA/ PYR a LMW/HMW.

Fig. 2: PAH diagnostic plots and ratios. (a) FLA/FLA + PYR over LMW/HMW, FLA = fluoranthene, PYR = pyrene ratio; LMW/ HMW = low molecular weight/high molecular weight (b) LMW/ HMW over BAA/(BAA + CHR), BAA = benz[a]anthracene, CHR = chrysene; (c) FLA/FLA + PYR over IPR/IPR + BGP, IPR = indeno[1,2,3-cd]pyrene, BGP = Benzo[g, h,i]perylene; (d) depth profiles of FLA/ PYR and the ratio of LMW/HMW.

doklad spalování uhlí a jsou také emitovány do prostředí z fosilních paliv. Ve vzorcích (tab. 3) byl nejvíce zastoupen hopan se strukturou H29 17 $\alpha(\mathrm{H}), 21 \beta(\mathrm{H})$ nor hopan, zatímco koncentrace dalších hopanů byly nižší a klesaly v tomto pořadí: $\mathrm{H} 30(17 \mathrm{aH}-21 \mathrm{bH})$ hopan, H31R (22R 17aH-21bH) homo hopan a H31S (22S 17aH-21bH) homo hopan. Poměr $S$ / $(S+R)$ lze použít pro identifikaci původu hopanů, kde $\mathrm{S}$ a R označuje prostorovou orientaci molekuly. V našich vzorcích se hodnota tohoto indexu pohybovala v rozmezí od 0,48 po 0,6 , přičemž u hodnot 0,35 se uvažuje o původu ze spalování uhlí, zatímco hodnoty okolo 0,6 jsou typické pro ropné produkty a výfukové zplodiny (Seifert a Moldowan 1978; Oros a Simoneit 2000). Ve vzorcích byl detekován v menším množství i 16 a(H)-Phyllocladane, jenž patří mezi tetracyklické diterpeny a jedná se o specifický biomarker prrítomnosti uhelné hmoty v sedimentu (Simoneit 2005). Podíly TOC byly variabilní a pohybovaly se od 0,5 do 9,1\% s mediánem 5,1\%. Statisticky významná korelace mezi zrnitostí a obsahem TOC nebyla pozorována, ale byla nalezena mezi TOC a všemi stanovenými terpenoidy $\left(R^{2}>0,5\right)$.

\section{Diskuze}

Příbřežní tělesa jsou ze své podstaty útvary nestálé a náchylné na redistribuci při změně podmínek proudění, což se týká především jemnozrnnějších facií. Zjištěné koncentrace sumy PAU u všech vzorků překračují preventivní hodnotu $1 \mathrm{mg} / \mathrm{kg}$ pro zemědělské půdy (vyhláška č. 153/2016 Sb.). Vysoké koncentrace PAU a výsledky diagnostických poměrů ve studovaných vzorcích svědčí o blízkosti zdroje kontaminace. Mnohem vyšší koncentrace PAU (až 243,8 mg/kg) byly nalezeny v sedimentech mrtvého ramene na Loděnici, situovaném uprostřed studované oblasti (Sedláček et al. 2020). Tyto vysoké hodnoty byly naměřeny ve vrstvách s vysokým podílem uhelné hmoty, jenž byly uloženy v 70. letech 20. století, což byla doba intenzivní průmyslové produkce a těžby uhlí $\mathrm{v}$ regionu. Do nadloží koncentrace PAU klesaly a v podpovrchových vrstvách byly stabilně okolo $10-15 \mathrm{mg} / \mathrm{kg}$. I když je pro ostravskou aglomeraci typická komplexnost zdrojů znečištění (Geršlová a Schwazbauer 2014) a emise látek se rychle promíchávají, ukazují diagnostické poměry u zkoumaných vzorků shodně na petrogenní původ PAU přes přímý vstup do říčního systému $z$ odpadního 
Tab. 3: Koncentrace specifických biomarkerů a celkového organického uhlíku (TOC): $16 \alpha(\mathrm{H})$-Phyllocladan, H29 = hopan se strukturou H29 17a(H), 21ß(H); H30 = hopan se strukturou $17 \alpha(\mathrm{H}), 21 \beta(\mathrm{H})-30 ; \mathrm{H} 31 \mathrm{R}=$ hopan se strukturou $17 \alpha(\mathrm{H})$, $21 \beta(\mathrm{H})-22 \mathrm{R} ; \mathrm{H} 31 \mathrm{~S}=$ hopan se strukturou $17 \alpha(\mathrm{H}), 21 \beta(\mathrm{H})-22 \mathrm{~S}$

Tab. 3: Concentrations of specific biomarkers and total organic carbon (TOC): $16 \alpha(\mathrm{H})$-Phyllocladane; $\mathrm{H} 29=\mathrm{H} 2917 \alpha(\mathrm{H}), 21 \beta(\mathrm{H})$ hopane; $\mathrm{H} 30=17 \alpha(\mathrm{H}), 21 \beta(\mathrm{H})-30$ hopane; H31R = 17 $\alpha(\mathrm{H}), 21 \beta(\mathrm{H})-22 \mathrm{R}-$ homo hopane; H31S = 17 $\alpha(\mathrm{H}), 21 \beta(\mathrm{H})-22 \mathrm{~S}$ -homo hopane.

\begin{tabular}{|l|c|c|c|c|c|c|}
\hline \multirow{2}{*}{ Vzorek } & \multicolumn{7}{|c|}{$\boldsymbol{\mu g} / \mathbf{k g}$} \\
\cline { 2 - 7 } & $\mathbf{1 6 a H}$ Phyllocladane & H29 & H30 & H31R & H31S & TOC (\%) \\
\hline ODB 1 & 79,2 & 60,5 & 59,8 & 45,5 & 34 & 4,8 \\
\hline ODB 2 & 80,6 & 45,3 & 43,9 & 32,2 & 26,3 & 4,4 \\
\hline ODB 3 & 62,9 & 46,1 & 47,1 & 35,0 & 26,7 & 8,0 \\
\hline ODB 4 & 82,2 & 58,6 & 58,8 & 45,5 & 32,1 & 5,0 \\
\hline ODB 5 & 41,6 & 20,7 & 20,1 & 15,4 & 16,7 & 1,6 \\
\hline ODB 6 & 85,1 & 41,6 & 40,0 & 29,2 & 23,0 & 5,0 \\
\hline ODB 7 & 91,1 & 41,4 & 39,0 & 27,8 & 25,9 & 7,1 \\
\hline ODB 8 & 53,9 & 40,3 & 38,1 & 28,3 & 25,7 & 5,8 \\
\hline ODB 9 & 70,4 & 36,0 & 37,4 & 21,7 & 21,3 & 5,1 \\
\hline ODB10 & 38,9 & 10,7 & 12,9 & 10,4 & 9,9 & 0,5 \\
\hline ODB 11 & 65,2 & 29,3 & 29,2 & 21,0 & 18,7 & 4,7 \\
\hline ODB 12 & 54,3 & 41,6 & 37,3 & 26,8 & 22,2 & 5,6 \\
\hline OB 1 & 181,5 & 101,6 & 89,6 & 69,0 & 46,2 & 9,1 \\
\hline OB 4 & 136,3 & 74,1 & 68,5 & 52,7 & 36,4 & 9,1 \\
\hline
\end{tabular}

systému nebo průsaky (Tobiszewski a Namiesnik 2012). Petrogenní PAU se vyskytují v okolí míst zplyňování uhlí, dehtu a zařízení na zpracování ropy. Nedávno byly vysoké hodnoty PAU dokumentovány v Černém př́ikopu v Ostravě (Janáková et al. 2010). Průkazná sekundární sorpce PAU na uhelnou hmotu nebyla ve studovaných vzorcích pozorována, ačkoliv část vzorků jeví slabou korelaci mezi obsahy PAU a terpenoidy. Tento fakt může být způsoben velmi malými koncentracemi uhelné hmoty v sedimentu. Stereochemická konfigurace na pozici C17 a C21 hopanů je využívána pro určení geologického stáří uhlí. Ve vzorcích byl zastoupen zejména hopan se strukturou H29 $17 \alpha(\mathrm{H}), 21 \beta(\mathrm{H})$, který je odvozen z černého uhlí (Oros a Simoneit 2000). Lze předpokládat, že část organické hmoty je degradována na $\mathrm{CO}_{2}$, protože príbřežní tělesa jsou vystavena oxidačnímu prostředí. Za podmínek vystavení slunečnímu záření také může docházet $\mathrm{k}$ degradaci některých PAU fotooxidací (Wang et al. 2014; Ward et al. 2018). Hodnoty PAU mohou kolísat i v průběhu roku, jak bylo popsáno ve fluviálních sedimentech $\mathrm{z}$ povodí řeky Moravy (Nehyba et al. 2010).

Vesměs stopové hodnoty OCP poukazují na skutečnost, že v povodí řeky Odry jsou stále přítomny perzistentní organické polutanty, což je důsledek intenzivní zemědělské a průmyslové produkce v minulých dekádách. Pouze u čtyř vzorků byly zjištěny koncentrace lehce překračující preventivní hodnotu $0,02 \mathrm{mg} / \mathrm{kg}$ pro zemědělské půdy (vyhláška č. 153/2016 Sb.). Podobně přítomnost zbytkového množství metabolitů DDT svědčí o jejich původu ze starých ekologických zátěží (Holoubek et al. 2007). Koncentrace DDE byly o něco vyšší oproti DDD, což bylo patrně způsobeno aerobní degradací DDT (Sedláček et al. 2020). HCB, dříve používaný jako fungicid, je v současnosti vedlejší produkt některých chemických povozů, což může být důvod přítomnosti stopových koncentrací v sedimentech (Sedláček et al. 2020). Vyšší koncentrace PCB v řece Odře u Bohumína byly zaznamenány po povodních $\mathrm{v}$ roce 1997 (Ministerstvo životního prostředí 2000). Koncentrace HCB a PCB vykazovaly statisticky významnou pozitivní korelaci s TOC, zatímco u PAU nebyla tato korelace prokázána (obr. 3). Všechny studované skupiny polutantů také jeví rozdílnou korelaci se zrnitostí sedimentu. PAU vykazuje pouze slabou korelaci s podílem písčité frakce $\left(\mathrm{R}^{2}=0,35\right)$. Některé studie již dříve prokázaly souvislost vyšších koncentrací PAU v sedimentech s vysokým podílem písčité frakce (Yang et al. 2008) i s ohledem na vyšší podíl uhelného materiálu $\mathrm{v}$ písčité frakci (Hofmann et al. 2007; Sedláček et al. 2020). Skupina PCB jeví slabou korelaci taktéž s písčitou frakcí.

\section{Závěr}

Obecně lze konstatovat, že riziko kontaminace fluviálních systémů je největší v blízkosti zdrojů znečištění a klesá po proudu, tedy s rostoucí vzdáleností (Ciazela et al. 2018) v důsledku naředění neznečištěným sedimentem. Zvýšené koncentrace PAU ve studovaných vzorcích svědčí
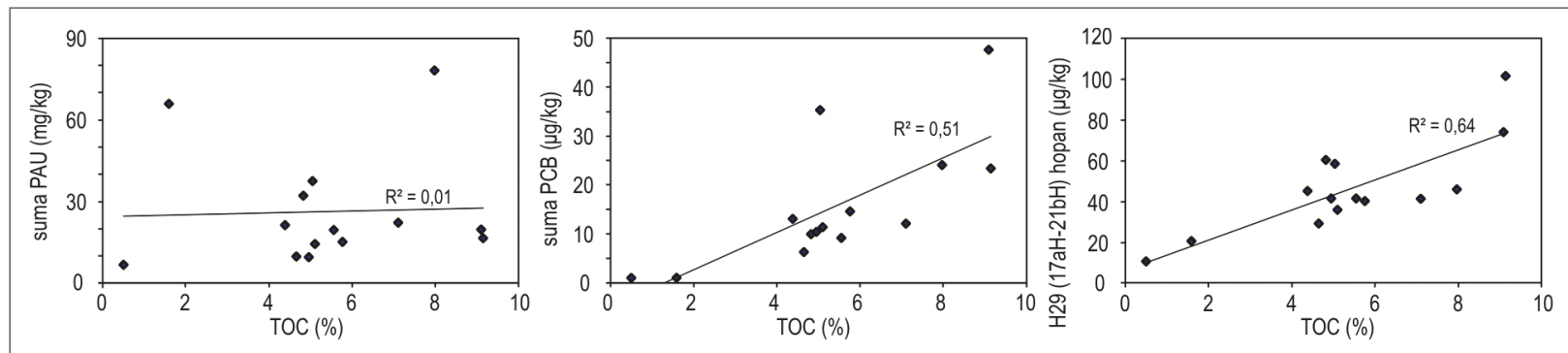

Obr. 3: Závislost mezi celkovým organickým uhlíkem (TOC) a koncentracemi PAU, PCB a hopanu se strukturou H29 17a(H), $21 \beta(\mathrm{H})$.

Fig. 3: Dependence between total organic carbon (TOC) and concentrations of PAHs, PCBs and H29 17 $\alpha(\mathrm{H}), 21 \beta(\mathrm{H})$ hopane. 
o tom, že zdroj se nachází v ostravské aglomeraci. Velkou roli v transportu hraje typ koryta. Přirozené říční systémy nabízí větší množství sedimentačních pastí (jako jsou břežní tělesa a mrtvá ramena) v porovnání s antropogenně upravenými koryty. Zvýšené koncentrace organických polutantů ve studovaných vzorcích proto mohou být důsledkem blízkosti zdroje kontaminace a přirozeného charakteru řeky, jenž dovoluje vytvoření prríbřežních sedimentárních těles. Tato studie prokázala, že břežní sedimentární tělesa vodních toků jsou vhodná pro odhad současných koncentrací organických polutantů. Dalším studiem této oblasti a odběrem většího množství vzorků lze získat přesnější výsledky o úrovních kontaminace jednotlivými organickými polutanty, což následně umožnuje interpretovat jejich pravděpodobné zdroje.

\section{Poděkování}

Tento výzkum byl finančně podpořen grantem IGA_PrF 2020_031 (Sedimenty jako environmentální archivy). Autoři děkují E. Geršlové a M. Havelcovéza cennépřipomínky k manuskriptu, které výrazně zkvalitnily finální podobu př́spěvku.

\section{Literatura}

Ciazela, J., Siepak, M., Wojtowicz, P. (2018). Tracking heavy metal contamination in a complex river-oxbow lake system: Middle Odra Valley, Germany/Poland. - Science of the Total Environment, 616-617, 996-1006. https://doi.org/10.1016/j.scitotenv.2017.10.219

Covaci, A., Gheorghe, A., Hulea, O., Schepens, P. (2006). Levels and distribution of organochlorine pesticides, polychlorinated biphenyls and polybrominated diphenyl ethers in sediments and biota from the Danube Delta, Romania. - Environmental Pollution, 140, 136-149. https://doi.org/10.1016/j.envpol.2005.06.008

Geršlová, E., Schwarzbauer, J. (2014). Hydrocarbon-based indicators for characterizing potential sources of coal derived pollution in the vicinity of the Ostrava City. - Environmental Earth Sciences, 71, 3211-3222. https://doi.org/10.1007/s12665-013-2709-0

Hofmann, T., Pies, C., Yang, Y. (2007). Elevated polycyclic aromatic hydrocarbons in a river floodplain soil due to coal mining activities. - Water Supply, 7(3), 69-74. https://doi.org/10.2166/ws.2007.068

Holoubek, I., Klánová, J., Jarkovský, J., Kubík, V., Helesic, J. (2007). Trends in background levels of persistent organic pollutants at Kosetice observatory, Czech Republic. Part II. Aquatic and terrestrial environments 1996-2005. - Journal of Environmental Monitoring, 9, 564-571. https://doi.org/10.1039/B701096F

Janáková, I., Mucha, N., Fečko, P. (2010). Flotation of river-born sediment from the old ecological load of Černý př́íkop in Ostrava, Czech Republic. - Mineralia Slovaca, 42, 309-312.

Kleineidam, S., Schüth, C., Grathwohl, P. (2002). Solubility normalized combined adsorption-partitioning sorption isotherms for organic pollutants. - Environmental Science \& Technology, 36, 21, 4689-4697. https://doi.org/10.1021/es010293b

Konat, J., Kowalewska, G. (2001). Polychlorinated biphenyls (PCBs) in sediments of the southern Baltic Sea-trends and fate. Science of the Total Environment, 280, 1-15. https://doi.org/10.1016/S0048-9697(01)00785-9

Ministerstvo životního prostředí (2000). Statistická ročenka životního prostředí České republiky. - Cenia, Česká informační agentura životního prostředí, Praha.

Nehyba, S., Hilscherová, K., Jarkovský, J., Dušek, L., Kuchovský, T., Zeman, J., Klánová, J. (2010). Grain size, geochemistry and organic pollutants in modern fluvial deposits in eastern Moravia (Czech Republic). - Environmental Earth Sciences, 60, 591-602. https://doi.org/10.1007/s12665-009-0199-x

Oros, D. R., Simoneit, B. R. T. (2000). Identification and emission rates of molecular tracers in coal smoke particulate matter. Fuel, 79, 515-536. https://doi.org/10.1016/S0016-2361(99)00153-2

Sedláček, J., Tolaszová, J., Křriženecká, S., Bábek, O., Zimová, K. (2020). Regional Contamination History Revealed in Coal-Mining-Impacted Oxbow Lake Sediments. - Water, Air, \& Soil Pollution, 231, 208. https://doi.org/10.1007/s11270-020-04583-1

Seifert, W. K., Moldowan, J. M. (1978). Applications of steranes, terpanes, and monoaromatics to the maturation, migration, and source of crude oils. - Geochimica et Cosmochimica Acta, 42, 77-95. https://doi.org/10.1016/0016-7037(78)90219-3

Simoneit, B. R. T. (2005). A review of current applications of mass spectrometry for biomarker/molecular tracer elucidations. Mass Spectrometry Reviews, 24, 719-765. https://doi.org/10.1002/mas.20036

Tobiszewski, M., Namiesnik, J. (2012). PAH diagnostic ratios for the identification of pollution sources. - Environmental Pollution, 162, 110-119. https://doi.org/10.1016/j.envpol.2011.10.025

Yang, Y., Ligoius, B., Pies, C., Grathwohl, P., Hofmann, T. (2008). Occurrence of coal and coal-derived particle-bound polycyclic aromatic hydrocarbons (PAHs) in a river floodplain soil. - Environmental Pollution, 151, 121-129. https://doi.org/10.1016/j. envpol.2007.02.020

Yunker, M. B., Macdonald, R. W., Vingarzan, R., Mitchell, R. H., Goyette, D., Sylvestre, S. (2002). PAHs in the Fraser River basin: a critical appraisal of PAH ratios as indicators of PAH source and composition. - Organic Geochemistry, 33, 489-515. https://doi.org/10.1016/S0146-6380(02)00002-5

Wang, C., Chen, B., Zhang, B., Guo, P., Zhao, M. (2014). Study of weathering effects on the distribution of aromatic steroid hydrocarbons in crude oils and oil residues. - Environmental Sciences: Processes Impacts, 16, 2408-2414.

Ward, P., Sharpless, C. M., Valentine, D. L., French-McCay, D. P., Aeppli, C., White, H. K., Rodgers, R. P., Gosselin, K. M., Nelson, R. K., Reddy, C. M. (2018). Partial photochemical oxidation was a dominant fate of Deepwater Horizon surface oil. - Environmental Science \& Technology, 52, 1797-1805. https://doi.org/10.1021/acs.est.7b05948 